\title{
Publisher Correction: Discovery of four Noggin genes in lampreys suggests two rounds of ancient genome duplication
}

\author{
Galina V. Ermakova, Alexander V. Kucheryavyy, Andrey G. Zaraisky \& Andrey V. Bayramov (D)
}

Correction to: Communications Biology https://doi.org/10.1038/s42003-020-01234-3, published online 10 September 2020.

The author affiliations in the original published version of the Article were inadvertently swapped so that the correct information for affiliation 1 was listed under affiliation 2, and vice versa. The correct author affiliations are shown below. The error has been corrected in the HTML and PDF versions of the Article.

Galina V. Ermakova ${ }^{1}$, Alexander V. Kucheryavyy ${ }^{2}$, Andrey G. Zaraisky ${ }^{1}$, Andrey V. Bayramov ${ }^{1}$

${ }^{1}$ Shemyakin-Ovchinnikov Institute of Bioorganic Chemistry, Russian Academy of Sciences, Moscow 117997, Russia

${ }^{2}$ Severtsov Institute of Ecology and Evolution, Russian Academy of Sciences, Moscow 119071, Russia

Published online: 21 September 2020

\footnotetext{
(c) (i) Open Access This article is licensed under a Creative Commons Attribution 4.0 International License, which permits use, sharing, adaptation, distribution and reproduction in any medium or format, as long as you give appropriate credit to the original author(s) and the source, provide a link to the Creative Commons license, and indicate if changes were made. The images or other third party material in this article are included in the article's Creative Commons license, unless indicated otherwise in a credit line to the material. If material is not included in the article's Creative Commons license and your intended use is not permitted by statutory regulation or exceeds the permitted use, you will need to obtain permission directly from the copyright holder. To view a copy of this license, visit http://creativecommons.org/licenses/by/4.0/.
}

(c) The Author(s) 2020 